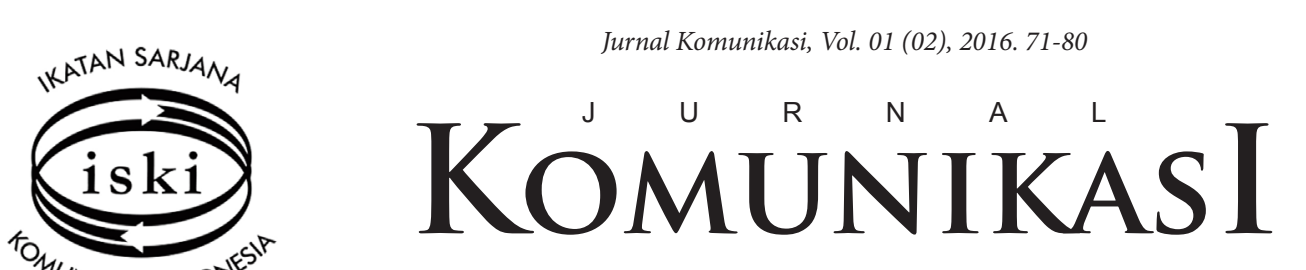

E-ISSN: 2503-0795

IKATAN SARJANA KOMUNIKASI INDONESIA

\title{
DISONANSI KOGNITIF PADA PERILAKU SEKS PRANIKAH
}

\author{
Inge Hutagalung \\ Program Magister Ilmu Komunikasi Universitas Mercu Buana \\ Jl. Meruya, Kembangan, Jakarta \\ inge_hutagalung@yahoo.com
}

\begin{abstract}
Abstrak
Survei Perkumpulan Keluarga Berencana Indonesia (PKBI) tahun 2015 tentang perilaku seks pranikah di kalangan remaja menunjukkan, 30 persen responden telah melakukan hubungan seksual sampai tahap penetrasi. Kenyataan akan perkembangan perilaku seks pranikah ini membentuk sikap permisif yakni sikap positif terhadap perilaku seks pranikah. Fokus penelitian adalah disonansi kognitif pada sikap permisif terkait perilaku seks pranikah di kalangan remaja. Metode penelitian yang digunakan adalah Interpretative Phenomenological Analyses (IPA) atau Analisis Fenomenologis Interpretatif. Hasil penelitian memperlihatkan, pada informan yang tidak mengalami disonansi maka proses komunikasi berbentuk tindakan untuk tidak melakukan perubahan apapun pada salah satu elemen disonansi, seperti merubah keyakinan/kepercayaan atau merubah tindakan; tidak menambahkan elemen kognitif konsonan baru dalam hal ini termasuk upaya secara aktif untuk mencari informasi lain yang mendukung keyakinan yang dimiliki. Pada informan yang mengalami disonansi, dalam upaya mencapai konsistensi kognitif maka individu akan mencari informasi lain yang dapat mendukung tindakannya untuk menjauhi perilaku seks pranikah.
\end{abstract}

Kata Kunci: Sikap Permisif, Disonansi, Elemen Kognitif Konsonan, Seks Pranikah.

\section{PENDAHULUAN}

Filsuf Belanda, Baruch Spinoza, 300 tahun yang lalu menyatakan manusia adalah mahluk sosial yang cenderung selalu hidup bermasyarakat dan berperilaku selaras dengan lingkungannya. Manusia adalah bagian dunia keteraturan yang alamiah dan rasional sehingga mempunyai tanggung jawab satu dengan yang lain, dan secara bersama mengejar keharmonisan (David Schneider, dalam Sarwono, 1999:37).

Jean Piaget, seorang psikolog Swiss (18961980) melalui teori perkembangan kognitif juga menyatakan bahwa seorang individu dalam hidupnya akan selalu berinteraksi dengan lingkungan. Dengan berinteraksi, seseorang akan memperoleh skema (schemata). Skema berupa kategori pengetahuan yang membantu individu dalam menginterpretasi dan memahami lingkungannya. Skema juga menggambarkan tindakan baik secara mental maupun fisik yang terlibat dalam memahami atau mengetahui sesuatu. Dalam pandangan Piaget, skema mencakup baik kategori pengetahuan maupun proses perolehan pengetahuan tersebut.

Konsep konsistensi dalam kognisi manusia Jean Piaget, dikembangkan dalam konsistensi perilaku oleh Kurt Lewin, melalui teorinya yang terkenal yaitu teori lapangan (field theory). Dengan teorinya, Lewin menjelaskan apa yang terjadi dalam jiwa seseorang sehingga membentuk persepsi dan perilaku yang bersifat menyeluruh. Menurut Lewin, perilaku (behavior) merupakan fungsi darikeadaan dirisendiri (personality) dan lingkungan. Faktor-faktor dari dalam maupun luar pribadi akan terpetakan dalam lapangan kesadaran manusia, dan berpengaruh pada pembentukan persepsi dan perilaku. Lapangan kesadaran ini digambarkan Lewin sebagai lapangan yang terbagi-bagi dalam berbagai wilayah. Tiap wilayah mewakili sesuatu dari dalam diri (aku, 
tubuhku) dan dari luar (ibuku, rumahku, temanku, makananku, dan sebagainya). Makin banyak pengalaman seseorang makin majemuk keadaan lapangan psikologiknya (Sarwono, 1999:82-84; Hall \& Lindzey, 1978:275-279).

Pada tahap selanjutnya, pemikiran Lewin dikembangkan oleh Festinger dan menjadi dalil utama teori disonansi kognitif, yaitu bahwa jika terjadi konflik dalam lapangan kesadaran (kognisi) seseorang maka keadaan ini akan menimbulkan ketidaknyamanan psikologis. Ketika ada ketidaknyamanan psikologis ataupun ketidaksesuaian (inkonsistensi) dalam kognisi, maka akan timbul disonansi.

Teori disonansi kognitif (cognitive dissonance theory) merupakan salah satu teori kognitif yang mempelajari sikap dengan penekanan pada konsistensi kognitif, lebih khusus tentang bagaimana perilaku memengaruhi sikap, yang diperkenalkan oleh Leon Festinger pada tahun 1957. Hingga kini teori ini menurut sejumlah ahli disebut sebagai teori konsistensi kognitif yang telah menghasilkan jumlah data empiris terbesar, dan paling berpengaruh dalam kajian psikologi sosial (Brehm \& Cohen, dalam Bem 1967:183; Zajonc, 1990:661; Littlejohn \& Foss, 2005:77; Griffin, 2006:239; Perloff, 2010:256; Tankard dan Werner, 2008:165). Para ahli psikologi sosial umumnya sependapat dengan Festinger bahwa manusia pada dasarnya bersifat konsisten, dan orang akan berbuat sesuatu sesuai dengan sikapnya, sedangkan berbagai tindakannya pun akan bersesuaian satu dengan lain. Ada kecenderungan pada manusia untuk tidak mengambil sikap-sikap bertentangan satu sama lain, dan kecenderungan untuk menghindari tindakan yang tidak sesuai dengan sikap yang diyakininya.

\section{KERANGKA TEORITIS}

Berbagai keadaan di luar diri remaja terkait perilaku seks pranikah, seperti pola asuh orang tua yang cenderung men-tabukan informasi seksual, lingkungan sosial perkotaan yang semakin individualistis, rangsangan dari media elektronik dan cetak, pengaruh kelompok sebaya serta mitos hubungan seks, kemudian terakumulasi pada diri remaja dalam bentuk sikap permisif. Yang dimaksud dengan sikap permisif adalah sikap positif terhadap perilaku seks pranikah yang ditunjukkan dalam gaya berpacaran yang "serba boleh", mulai dari berciuman hingga akhirnya bersenggama, dimana sikap tersebut disepakati oleh kedua belah pihak atau "mau sama mau" (Clayton \& Bokemeier, 1980; Faturochman, 1992; Damayanti, 2007; Sarwono, 2007).

Sikap permisif yang timbul di kalangan remaja terkait perilaku seks pranikah, merupakan gambaran upaya manusia mencari konsistensi antara sikap-perilaku dipandang dari kondisi dimana proses perilaku memengaruhi sikap. Sikap ini juga merupakan upaya pembenaran dari perilaku remaja terkait seks pranikah. Dalam istilah psikoanalisis dari Freud dinamakan rasionalisasi (Sarwono, 2001:262; Sears et all, 1985:155-156). Maraknya sikap permisif ini menimbulkan pertanyaan: "Apakah sikap permisif tidak menimbulkan konflik bathin dalam diri remaja mengingat sikap permisif terkait seks pranikah sangat bertentangan dengan norma yang ada dalam masyarakat di Indonesia”. Dalam budaya masyarakat Indonesia perilaku seks yang dilakukan sebelum pernikahan yang resmi merupakan suatu larangan yang ditetapkan secara normatif (agama maupun kesusilaan). Masyarakat dituntut untuk menghormati norma yang berlaku, termasuk kalangan remaja. Tidak ada satupun agama yang berlaku di Indonesia menghalalkan perilaku seks pranikah, melainkan menistakan perilaku tersebut sebagai tindakan yang terlarang.

Dengan kata lain, sikap permisif dan norma masyarakat menjadi dua elemen kognitif (pikiran atau keyakinan) yang tidak selaras atau inkonsistensi. Jika pembenaran pada salah satu elemen kognitif tidak dapat dilakukan, maka ketegangan (disonansi) akibat pertentangan dua elemen kognitif akan tetap berlangsung.

Berdasarkan apa yang telah dipaparkan di atas, maka rumusan masalah penelitian adalah bagaimana remaja melakukan proses komunikasi persuasif untuk mencapai kondisi konsistensi dalam skema kognitif terkait sikap permisif terhadap perilaku seks pranikah. Untuk lebih memudahkan penelitian maka rumusan masalah adalah: (1) bagaimana pengalaman remaja melakukan proses komunikasi dalam upaya mencapai kondisi konsitensi kognitif terkait sikap permisif terhadap perilaku seks pranikah?; (2) mana yang paling berperan antara norma kelompok acuan dan norma masyarakat dalam menimbulkan disonansi terkait sikap permisif terhadap perilaku seks pranikah?

Untuk melakukan penelitian terkait konstruksi yang terbangun terhadap pesan yang diterima akan 
digunakan perspektif komunikasi berdasarkan disiplin ilmu psikologi dengan aliran kognitif. Yaitu suatu aliran dalam psikologi yang mempelajari bagaimana arus informasi yang ditangkap oleh indra diproses dalam jiwa seseorang sebelum diendapkan dalam kesadaran atau diwujudkan dalam bentuk tingkah laku.

Dalam teori komunikasi, teori-teori kognitif utamanya dipakai dalam kaitannya dengan produksi dan penafsiran pesan. Teori kognitif, memfokuskan pada karakter individual dan bagaimana karakter individual tersebut dihubungkan dengan berbagai perilaku pesan, efek situasi atas perilaku pesan, dan berkonsentrasi pada proses aktual pada produksi maupun pemrosesan dan penilaian pesan.

Salah satu teori yang berbicara mengenai organisasi sikap yang didasarkan pada prinsip konsistensi, lebih khusus berkaitan dengan pengaruh perilaku terhadap sikap, adalah teori disonansi kognitif (Cognitive Dissonance Theory).

Teori disonansi kognitif dipopulerkan Leon Festinger yang terkenal dan berpengaruh dalam sejarah psikologi sosial (Littlejohn, 2002:126). Teori disonansi kognitif adalah salah satu teori yang banyak dipakai dalam persuasi, terutama untuk memperkirakan apakah pesan-pesan persuasi sampai kepada khalayak penerima atau tidak. Teori ini berguna bagi para perancang pesan persuasi dalam merancang strategi persuasi agar pesan tersebut sampai pada khalayak tanpa menimbulkan disonansi (lihat West and Turner, 2007).

Dalam bukunya "A Theory of Cognitive Disonance", Leon Festinger (1957) mengemukakan bahwa teorinya banyak dipengaruhi oleh pemikiran teori psikologi lapangan (field theory) dari Kurt Lewin, yang merupakan pengembangan dari konsep konsistensi dalam kognisi manusia yang dikenalkan oleh Jean Piaget.

Pada tahap selanjutnya, inti pemikiran Lewin dikembangkan oleh Festinger dan menjadi dalil utama teori disonansi kognitif. Disonansi kognitif di deskripsikan sebagai suatu kondisi yang membingungkan, yang terjadi ketika individu "menemukan diri melakukan sesuatu yang tidak sesuai dengan apa yang diketahui, atau mempunyai pendapat yang tidak sesuai dengan pendapat lain yang diyakini”. Dengan kata lain, teori disonansi kognitif berkaitan dengan dua jenis inkonsistensi perilakusikap tertentu, yang timbul karena dilakukannya perilaku-yang-tidak-sesuai dengan sikap dan yang timbul karena pengambilan keputusan. Dalam hal terjadinya disonansi maka akan timbul ketegangan psikologis, atau ketidaknyamanan (Festinger, 1957:3; Sears, et.al, 1985:156-157; Littlejohn \& Foss, 2005:77; Griffin, 2006:228,237; Perloff, 2010:238; Tankard dan Werner, 2008:165).

Gambar 2.2. Cognitive Dissonance Theory

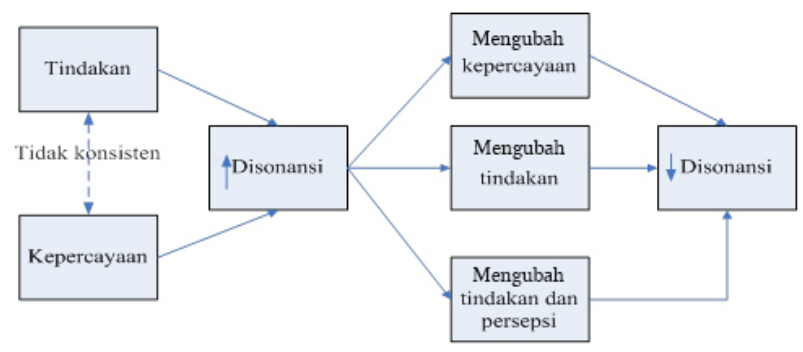

Sumber: Festinger (1957)

Pengalaman disonansi (sikap dan tindakan yang tidak sesuai atau dua keyakinan yang tidak selaras) merupakan kondisi kejiwaan yang tidak menyenangkan, dan mengakibatkan tekanan internal yang memotivasi individu untuk melakukan upaya menghindari peningkatan disonansi. Ada tiga proses komunikasi yang dapat dilakukan untuk mengurangi disonansi, yaitu cara pertama dengan melakukan perubahan pada salah satu elemen disonansi, seperti merubah elemen kognitif lingkungan (merubah keyakinan/kepercayaan, sikap, pendapat), atau merubah elemen kognitif perilaku (merubah tindakan). Namun, kadangkala perubahan lingkungan atau perubahan perilaku tidak menurunkan disonansi. Menyikapi kondisi ini individu akan menghadapkan diri pada cara kedua, yaitu penambahan beberapa elemen kognitif konsonan baru, dalam hal ini termasuk upaya secara aktif untuk mencari informasi-informasi baru. Adapun cara ketiga, yaitu menurunkan arti penting dari elemen-elemen yang mempunyai hubungan dengan elemen kognitif disonan (trivialization). (Leon Festinger, 1957:19; Roger Brown, 1965; Baron \& Byrne, 1994; Sarwono, 1999:112-114; Littlejohn \& Foss, 2005:78; O’Keefe, 2002:79).

Upaya untuk mengurangi disonansi juga mendorong proses perilaku komunikasi persuasif, yaitu individu akan mencari informasi yang konsonan dengan keyakinan atau sikap diri. Untuk itu individu secara aktif akan mencari dan melakukan pilihan terhadap materi informasi maupun situasi yang 'sama dan sebangun' dengan sikap mereka. Dan, menolak 
serta menghindari (avoidance) semua materi informasi yang bertentangan dengan keyakinan atau sikap mereka (Festinger, 1957:13; O'Keefe, 2002:8586; Griffin, 2006:229-230; Tankard dan Werner, 2008:167-171).

\section{METODE PENELITIAN}

Pada penelitian ini, paradigma yang digunakan adalah post-positivistik. Alasan peneliti memilih paradigma post-positivistik dikarenakan teori disonansi kognitif adalah konsep positivistik namun untuk mendalaminya dibutuhkan analisa kualitatif. Penelitian dengan paradigma post-positivistik dalam penelitian ini membantu untuk mengeksplorasi dan memahami apa yang ada dibalik fenomena, latar belakang pemikiran individu atau subjek penelitian yang terlibat di dalamnya. Jadi, penelitian ini dalam rangka mengeksplorasi fenomena atau pengalaman seseorang terhadap sikap permisif yang timbul di kalangan remaja terkait perilaku seks pranikah, sebagai gambaran upaya manusia mencari konsistensi antara sikap-perilaku dipandang dari kondisi dimana proses perilaku memengaruhi sikap. Adapun objek penelitian ini adalah remaja di Kelurahan Rawa Buaya, Jakarta Barat.

Metode penelitian yang digunakan dalam penelitian adalah Interpretative Phenomenological Analyses (IPA) atau Analisis Fenomenologis Interpretatif. Menurut Smith and Osborn (2009:97), tujuan dari Analisis Fenomenologis Interpretatif adalah mengukur secara detail bagaimana partisipan memaknai dunia personal dan sosialnya. IPA merupakan pendekatan yang cocok ketika seseorang berusaha mengetahui bagaimana individu mempersepsi situasi-situasi tertentu yang dihadapinya. Ketika seseorang berhadapan dengan kompleksitas, proses, atau sesuatu yang baru.

Berdasarkan tujuan penelitian, penelitian ini akan menganalisis bagaimana proses komunikasi yang dilakukan remaja dalam upaya mencapai kondisi konsistensi kognitif terkait sikap permisif terhadap perilaku seks pranikah. Oleh karena itu, peneliti menggunakan metode wawancara semiterstruktur sebagai metode untuk mengumpulkan data. Wawancara semi terstruktur sebagai instrumen pengumpulan data yang fleksibel. Wawancara jenis ini memungkinkan peneliti dan informan melakukan dialog, dan pertanyaan-pertanyaan yang telah disusun sebelumnya dapat dimodifikasi menurut respons informan (Smith and Osborn, 2009:105).
Data dan informasi yang diperoleh dari hasil wawancara dikumpulkan lalu dianalisis melalui proses reduksi data atas seluruh pernyataan hasil wawancara, dan dirumuskan menjadi esensi pengalaman. Terdapat dua tahapan dalam melakukan reduksi data, yaitu: (1) melakukan editing, pengelompokan, dan meringkas data; dan (2) menyusun kode-kode dan catatan-catatan mengenai berbagai hal, termasuk yang berkenaan dengan aktivitas serta proses-proses dan menyusunnya menjadi kategori serta merangkumnya menjadi pola dan susunan yang sederhana. Setelah proses reduksi, dilakukan tahapan pengorganisasian data secara sistematis, yaitu menjalin data yang satu dengan kelompok data yang lain sehingga seluruh data yang dianalisis benar-benar dilibatkan dalam satu kesatuan karena dalam penelitian kualitatif data sangat mungkin bertumpuk.

\section{HASIL PENELITIAN}

Informan dalam penelitian ini berjumlah delapan orang. Dalam sajian hasil penelitian ini, kedelapan informan menggunakan nama inisial sesuai dengan kesepakatan dengan para informan. Ke delapan informan merupakan remaja yang tergabung dalam kelompok sebaya (peer group) tertentu, seperti kelompok tari, kelompok pengajian, kelompok diskusi, kelompok hobby.

\section{Disonansi Kognitif terkait Sikap Permisif} terhadap Perilaku Seks Pranikah

Pada konteks penelitian ini, disonansi kognitif umumnya dihadapi oleh para informan dikarenakan adanya konflik bathin dalam diri remaja mengingat sikap permisif terhadap perilaku seks pranikah sangat bertentangan dengan kepercayaan (belief) yang dimiliki, khususnya yang berasal dari nilainilai pendidikan keluarga.

Dari delapan informan, satu informan mengaku mengalami kebingungan, kebimbangan, dan ketidaknyamanan terkait sikap permisif terhadap perilaku seks pranikah. Namun, tujuh informan lainnya tidak mengalami hal serupa. Mereka dari awal sudah yakin dengan keyakinan (belief) yang dimiliki. Yaitu, bahwa sikap permisif terhadap perilaku seks pranikah adalah bertentangan dengan norma, baik agama maupun sosial masyarakat. Perbedaan ini dapat dilihat sebagai upaya masingmasing informan dalam mengolah informasi atau pesan yang diperoleh terkait perilaku seks pranikah. Hal ini dapat digambarkan sesuai dengan apa yang 
Tabel Deskripsi Umum Informan

\begin{tabular}{|l|l|l|l|l|}
\hline DESKRIPSI & 1: AN & 2: FD & 3: AR & 4: SS \\
\hline Jenis Kelamin & Pria & Perempuan & Perempuan & Pria \\
\hline Pendidikan & S1 & S1 & SMA & S1 \\
\hline Usia & 19 tahun & 19 tahun & 20 tahun & 19 tahun \\
\hline $\begin{array}{l}\text { Keterlibatan } \\
\text { dalam kelompok } \\
\text { sebaya }\end{array}$ & - Kelompok Futsal & $\begin{array}{l}\text { - Kelompok Tari } \\
\text { Tradisional }\end{array}$ & $\begin{array}{l}\text { - Remaja } \\
\text { Mesjid }\end{array}$ & $\begin{array}{l}\text { - Kelompok } \\
\text { Pecinta } \\
\text { Alam } \\
\text { - Remaja Mesjid } \\
\text { Mesjid }\end{array}$ \\
\hline
\end{tabular}

\begin{tabular}{|c|c|c|c|c|}
\hline DESKRIPSI & 5: LK & 6: YS & 7: PI & 8: WA \\
\hline Jenis Kelamin & Pria & Perempuan & Pria & Perempuan \\
\hline Pendidikan & S1 & S1 & SMA & SMA \\
\hline Usia & 19 tahun & 18 tahun & 17 tahun & 17 Tahun \\
\hline $\begin{array}{l}\text { Keterlibatan } \\
\text { dalam kelompok } \\
\text { sebaya }\end{array}$ & $\begin{array}{l}\text { - Kelompok } \\
\text { Pecinta Alam } \\
\\
\text { - Kelompok } \\
\text { Sepak Bola }\end{array}$ & $\begin{array}{l}\text { - Kelompok } \\
\text { Kuliner } \\
\text { - Kelompok } \\
\text { Pengajian }\end{array}$ & $\begin{array}{ll}\text { - } & \text { Kelompok } \\
& \text { Futsal } \\
\text { - } & \text { Ketua OSIS }\end{array}$ & $\begin{array}{l}\text { - Kelompok } \\
\text { Tari } \\
\text { - Osis bidang } \\
\text { Olahraga }\end{array}$ \\
\hline
\end{tabular}

diucapkan oleh informan.

Informan PI mengaku bingung terkait sikap permisif terhadap perilaku seks pranikah. Hal ini dikarenakan banyaknya teman-teman yang melakukan seks bebas, dan membuat informan PI ingin melakukan perilaku seks pranikah.

"Jujur, ya sempat bingung, karena saya kerap melihat teman saya pacaran dan banyak yang terjerumus dalam seks bebas. Hal ini membuat saya ingin melakukannya, namun takut untuk melakukan ketika saya mengingat di mana saya hidup dalam keluarga yang agamis".

Sementara tujuh informan dengan tegas menyatakan bahwa mereka tidak bingung terkait sikap permisif terhadap perilaku seks pranikah. Hal ini dikarenakan dasar agama yang kuat dan pendidikan, nasehat maupun saran orang tua yang telah tertanam dalam keluarga sejak kecil.

Beberapa pernyataan para informan, antara lain:

Informan WA: "Saya sebagai seorang remaja yang notabene beragama Islam, yang dari kecil sudah dididik dengan adat dan istiadat yang kuat, melihat sikap permisif sebagai hal tidak boleh dilakukan karena bertentangan dengan agama dan ajaran orang tua".

Informan AN: "Sebagai anggota Genre (Generasi Berencana), saya tidak bingung sama sekali menghadapi perilaku seks bebas ini. Karena saya mengamati hal tersebut tidak memberikan dampak yang positif untuk diri saya pribadi, dan bertentangan dengan nasehat dari orang tua saya".

\section{Proses Komunikasi dalam Pencapaian Konsistensi Kognitif}

Pada konteks penelitian ini, proses komunikasi yang dilakukan oleh para informan dalam mencapai konsistensi kognitif dapat dijelaskan dalam tiga bentuk, yaitu: (1) melakukan perubahan pada salah satu elemen disonansi, seperti merubah keyakinan/ kepercayaan atau merubah tindakan; (2) Penambahan beberapa elemen kognitif konsonan baru, dalam hal ini termasuk upaya secara aktif untuk mencari informasi lain yang mendukung keyakinan yang dimiliki, dan (3) menurunkan arti penting dari 
elemen-elemen yang mempunyai hubungan dengan elemen kognitif disonan (trivialization).Yaitu, mempertimbangkan kembali bahwa disonansi yang terjadi bukanlah sesuatu yang penting.

Pada informan yang mengalami kebingungan, proses komunikasi untuk mencapai konsisten kognitif dilakukan dengan mencari informasi lain untuk mendukung sikap menolak sikap permisif terhadap perilaku seks pranikah.

"Saat dalam kebingungan, saya akan mencari dukungan informasi lain yang akan menguatkan diri saya bahwa sikap permisif adalah perbuatan yang terkutuk dan harus dijauhi".

Adapun tujuh informan lainnya dalam mencapai konsistensi kognitif telah menurunkan arti penting dari sikap permisif terhadap perilaku seks pranikah dengan menyatakan bahwa sikap permisif terhadap perilaku seks pranikah adalah sesuatu yang tidak perlu diperhatikan dan dihiraukan karena berpotensi merusak kehidupan masa depan. Beberapa pernyataan informan yang menegaskan proses komunikasi ini adalah sebagai berikut:

Informan YS: "Jujur, saya dikelilingi dengan teman-teman yang berperilaku seks bebas, namun menurut saya semua balik kepada diri kita sendiri. Kalau saya pribadi, tidak beranggapan bahwa perilaku seks bebas adalah hal yang perlu serius dicermati. Biar pun lingkungan saya seperti itu, namun saya yakin akan keyakinan saya bahwa hal itu adalah sesuatu yang dapat merusak kehidupan dan masa depan saya".

Informan SS: "Perilaku seks bebas itu.......tergantung pada bagaimana remaja menyikapinya. Kalau dasar agama dan pendidikan orang tua nya kuat, saya percaya pasti remajanya akan cuek aja menghadapi perilaku itu".

Informan WA: "Saya pribadi memiliki pengalaman di mana teman-teman banyak yang melakukan perilaku seks bebas. Saya tidak ambil pusing dengan mereka. Jika saya tahu teman ada yang berperilaku seperti itu, maka saya cukup tahu. Saya berjilbab dan sangat menjaga diri. Karena bagaimanapun yang dapat menjaga dan melindungi kehormatan diri adalah diri kita sendiri. Jadi saya tegas dalam hal perilaku seks pranikah. Buat saya masih banyak hal yang harus dipikirkan daripada memikirkan sikap permisif”.

\section{PERAN KELOMPOK TERHADAP SIKAP PERMISIF}

Menjawab pertanyaan terkait norma kelompok mana yang berperan dalam menimbulkan disonansi terkait sikap permisif terhadap perilaku seks pranikah, tujuh informan informan menyatakan bahwa norma keluarga/masyarakat memiliki peran yang sangat penting. Hal ini berarti norma dari kelompok sebaya memiliki kecenderungan kurang berperan dibandingkan norma keluarga yang telah membentuk keyakinan (belief) pada para informan. Sementara satu informan menyatakan bahwa norma kelompok memegang peranan penting terhadap sikap permisif terhadap perilaku seks pranikah. Beberapa pernyataan berikut akan memberikan gambaran akan peran norma kelompok terkait sikap permisif terhadap perilaku seks pranikah.

Informan PI: "Menurut saya norma dari keluarga lebih berperan karena ikatan bathin saya lebih kuat ke keluarga dan agama...., dibanding dengan kelompok teman2 saya. Saya dapat membentengi diri saya dari hal-hal yang buruk karena saya selalu ingat ajaran ibu saya. Saya juga takut pada Allah, karena menurut ibu saya, perilaku seks pranikah adalah hal yang dilarang oleh agama".

Informan AR: "Kelompok dari teman-teman saya tidak mempengaruhi sikap saya terhadap seks bebas, karena jaran agama dan orang tua tidak memperbolehkan kegiatan seperti itu. Saya mengikuti aturan tersebut dengan tidak mengikuti seks bebas yang marak terjadi di kalangan remaja saat ini".

Informan WA: "Kelompok teman sangat tidak mempengaruhi tentang penolakan saya mengenai perilaku seks bebas. Dikarenakan memang suatu perilaku seks bebas merupakan suatu sikap yang menyimpang dan agama juga melarang perilaku tersebut".

Informan SS: "Menurut saya yang lebih berperan adalah kepercayaan diri sendiri. Kepercayaan ini saya dapatkan dari pendidikan dalam keluarga saya. Keputusan yang saya ambil akan saya jalani dan lakukan sendiri. Resiko dan konsekuensi yang akan didapat akan hanya dirasakan oleh saya sendiri. Oleh karena itu, buat saya norma dan ajaran dari keluarga akan saya perhatikan. Waaupun saya sadar kalau saya mengikuti ajaran ibu saya, ada resiko dijauhi ataupun dikucilkan dari kelompok teman-teman saya. Dalam perilaku seks bebasm menurut saya kepercayaan agama, pendapat orang tua itu lebih utama. Jadi norma kelompok teman tidak terlalu 
perperan. Saya lebih memilih kepercayaan agama, yaitu meninggalkan perlkau seks bebas tanpa menilai norma kelompok teman saya".

Adapun pernyataan satu informan yang menyatakan bahwa norma kelompok memegang peranan penting terhadap sikap permisif terhadap perilaku seks pranikah adalah sebagai berikut:

Informan LK: "Menurut saya pengaruh norma kelompok pada lingkungan remaja di era sekarang sangatlah berperan besar dan mengambil andil yang besar pula pada diri dan psikologis diriseorang remaja. Karena pada faktanya sebagian waktu seorang remaja yang masih mencari jati diri terpakai/digunakan untuk bersosialisasi dengan teman di lingkungan sekitar. Saat teman-teman sepergaulan melakukan sesuatu atau mengatakan sesuatu ada pemikiran bahwa yang dilakukannya benar atau bisa juga salah. Namun pada saat ini banyak remaja yang hanya ingin berteman dengan orang-orang tertentu yang dianggap asyik untuk bergaul. Sehingga kadang banyak yang menanggapi setuju dengan apa yang teman dalam kelompok katakan........agar dia masih bisa berteman dengan kelompok tersebut dan melakukan perubahan pola pikir agar dapat selalu diterima oleh teman sepergaulannya".

Teori disonansi kognitif merupakan teori yang dipengaruhi ilmu psikologi. Sesuai dengan pemetaan tujuh tradisi Craig, Griffin mengelompokkan teori disonansi kognitif dalam tradisi socio-psychological (tradisi sosio-psikologis) (Griffin, 2006:22).

Tradisi sosiopsikologis adalah sebuah tradisi yang berasal dari kajian psikologi sosial. Kajian individu sebagai mahluk sosial merupakan tujuan dari tradisi sosiopsikologis. Tradisi ini memiliki tradisi yang kuat dalam komunikasi, dan melihat komunikasi sebagai pengaruh interpersonal. Tradisi ini juga membantu untuk memahami individu manusia sebagai pelaku komunikasi. Yaitu, bagaimana dan mengapa setiap individu berperilaku seperti yang mereka perbuat, serta memusatkan perhatian pada hubungan sebabakibat yang terjadi pada proses komunikasi dengan mempertimbangkan faktor yang mempengaruhi sebab akibat. Di sisi lain, tradisi sosiopsiklogis menolak pendapat yang menyatakan bahwa orang itu rasional, bahwa individu tahu apa yang dipikirkan dan persepsi itu dapat dilihat dengan jelas (Littlejohn, 2002:97-98, Littlejohn dan Foss, 2009:97).

Manusia tidak menanggapi lingkungannya secara otomatis. Perilaku manusia tergantung pada bagaimana mereka berpikir dan mempersepsi lingkungannya. Manusia adalah agen yang secara aktif menerima, menggunakan, memanipulasi, dan mengalihkan informasi. Manusia secara aktif berpikir, membuat rencana, memecahkan masalah, dan mengambil keputusan. Manusia memproses informasi dengan cara tertentu melalui struktur kognisi yang diberi istilah schema. Struktur kognisi (schema) bisa membantu manusia mencapai keterpaduan dengan lingkungan, dan membantu untuk menyusun realitas sosial. Sistem ingatan yang dimiliki oleh manusia diasumsikan terdiri atas struktur pengetahuan yang tak terhitung jumlahnya, dan merupakan hasil dari proses informasi yang datang dari lingkungan ke dalam struktur mental. Jadi untuk memperoleh informasi yang bisa dipercaya maka proses mental seseorang merupakan hal utama yang bisa menjelaskan perilaku sosial seseorang (Fiske and Taylor, 1991 dalam Littlejohn dan Foss 2009).

Pendekatan individualistis merupakan ciri tradisi sosiopsikologis. Hal ini dapat dipahami karena teori-teori tradisi ini muncul dan berkembang dalam lingkup budaya Barat. Individu telah mendominasi pemikiran Barat sejak pencerahan abad ke-18, dan merupakan unit analisis utama dalam kebanyakan pemikiran Barat. Individu dalam tradisi sosiopsikologis dilihat sebagai pelaku komunikasi sekaligus mahluk sosial. Pandangan psikologis ini melihat manusia sebagai kesatuan lahiriah dengan karakteristik yang mengarahkannya kepada perilaku mandiri. Pandangan ini juga melihat pikiran individu sebagai tempat memproses dan memahami informasi serta menghasilkan pesan, sekaligus juga mengakui kekuatan yang dapat dimiliki oleh individu melebihi individu lain, serta efek informasi pada pikiran manusia. Tradisi sosiopsikologis memberikan pemahaman apa yang ada di balik perilaku. Oleh karena itu, hampir tidak mengejutkan jika penjelasan-penjelasan psikologis begitu menarik bagi para ahli komunikasi, seperti apa yang menentukan gaya komunikasi seseorang, situasi komunikasi semacam apa yang disukai dan yang dihindari, apakah seseorang sama atau berbeda dengan orang lain dalam hal komunikasi, dan sebagainya (Littlejohn dan Foss, 2005:43; 2009:63, Samovar, et all, 2010:231).

Berbeda dengan Griffin, Littlejohn dan Foss menempatkan teori disonansi kognitif yang tergolong dalam teori pelaku komunikasi (komunikator) dalam tradisi sibernetika, yaitu tradisi yang menekankan 
hubungan timbal balik di antara semua bagian dari sebuah sistem.

Dalam sibernatika, komunikasi dipahami sebagai sistem bagian-bagian atau variabel-variabel yang saling memengaruhi satu sama lainnya, membentuk, serta mengontrol karakter keseluruhan sistem, dan layaknya organisme, menerima keseimbangan dan perubahan. Ide 'sistem' membentuk inti pemikiran Sibernetika. Sibernetika dalam kesan yang sempit dipopulerkan oleh Norbert Wiener pada tahun 1950an. Sebagai wilayah kajian, sibernetika merupakan cabang dari teori sistem yang memfokuskan diri pada putaran timbal balik dan proses-proses kontrol. Dengan menekankan pada kekuatan-kekuatan yang tidak terbatas, sibernetika menantang pendekatan linier yang menyatakan bahwa satu hal dapat menyebabkan hal lainnya. Sebagai gantinya, konsep ini mengarah pada pertanyaan tentang bagaimana sesuatu saling memengaruhi satu sama lainnya untuk mempertahankan keseimbangan. Tradisi sibernetika menjadi bagian dalam komunikasi yang populer dan berpengaruh bagi pemahaman komunikasi (pemahaman terhadap sebuah hubungan) secara umum (Littlejohn dan Foss, 2009:59-62).

Ada dua genre teori tentang pengolahan informasi dalam kelompok tradisi sibernetika, yaitu kelompok teori yang umumnya berasal dari rubrik penggabungan informasi (information-integration), dan kelompok teori yang dikenal sebagai teori konsistensi (consistency theories). Teori konsistensi dimulai dengan dasar pikiran bahwa individu lebih nyaman dengan konsistensi daripada inkonsistensi. Dalam bahasa sibernetika, manusia mencari homeostasis atau keseimbangan, dan sistem kognitif adalah sebuah alat utama yang dapat digunakan untuk mencapai keseimbangan. Salah satu teori konsistensi kognitif adalah disonansi kognitif karya Leon Festinger (1957) (Littlejohn dan Foss, 2005:77; 2009:110-116).

Teori disonansi kognitif mendeskripsikan disonansi kognitif sebagai suatu kondisi yang membingungkan, yang muncul akibat dua elemen kognitif yang bertentangan. Manakala seseorang menjadi bingung, aneh, sebal, dan mau marah, itulah antara lain tanda-tanda disonansi kognitif. Kondisi ini terjadi karena individu dihadapkan pada situasi di mana ada hal-hal yang menurut akal sehat seharusnya tidak terjadi tapi tetap terjadi (atau sebaliknya seharusnya terjadi, tetapi tidak terjadi).

Terkait dengan penelitian ini disonansi muncul berupa kebingungan, kebimbangan, dan ketidaknyamanan terkait sikap permisif terhadap perilaku seks pranikah. Hal ini yang dialami oleh salah satu informan. Dari pernyataan yang diberikan tergambar bahwa informan mengalami kondisi yang dilematis. Yaitu, informan kerap melihat teman-teman berpacaran dan melakukan seks bebas. Situasi ini membuat informan ingin ikut melakukan seks bebas. Di sisi lain, informan takut melakukan perilaku seks pranikah mengingat dirinya hidup dalam keluarga yang taat beragama.

Peneliti beranggapan bahwa disonansi yang terjadi pada salah satu informan adalah wujud upaya informan untuk mencari konsistensi kognitif sebagai bagian dari kelompok sebaya dan juga bagian dari keluarga. Konsistensi adalah prinsip aturan utama di dalam proses kognitif. Untuk mencapai sebuah konsistensi kognitif tidaklah menutup kemungkinan adanya suatu perubahan sikap sebagai jalan keluar untuk mencapai keseimbangan (balance). Prinsipnya manusia ingin mengembalikan konsistensi atau konsonansi (keseimbangan) antar kognitifnya, karena manusia memiliki hasrat akan adanya konsistensi pada keyakinan, sikap dan perilakunya.

Sementara pada tujuh (7) informan lainnya, peneliti berpendapat mereka berada dalam situasi konsonan. Situasi ini tercipta karena ketujuh informan sudah memiliki keyakinan (belief) yang kuat bahwa sikap permisif terhadap perilaku seks pranikah adalah bertentangan dengan norma agama maupun norma sosial/ masyarakat.

Lebih lanjut, proses komunikasi untuk mencapai konsistensi kognitif, berdasarkan pengalaman informan pada penelitian ini dapat dibagi dua. Yaitu, pertama, pada informan yang tidak mengalami disonansi maka proses komunikasi berbentuk tindakan untuk tidak melakukan perubahan apapun pada salah satu elemen disonansi, seperti merubah keyakinan/kepercayaan atau merubah tindakan; tidak menambahkan elemen kognitif konsonan baru dalam hal ini termasuk upaya secara aktif untuk mencari informasi lain yang mendukung keyakinan yang dimiliki. Peneliti berpendapat hal ini dilakukan karena para informan tidak berada dalam situasi inkonsistensi kognitif. Adapun untuk tetap berada dalam konsistensi kognitif, proses komunikasi yang dilakukan adalah menurunkan arti penting dari sikap permisif terhadap perilaku seks pranikah. Kedua, pada informan yang mengalami disonansi, dalam upaya mencapai konsistensi kognitif maka 
individu akan mencari informasi lain yang dapat mendukung tindakannya untuk menjauhi perilaku seks pranikah.

Di sisi lain, hasil penelitian memperlihatkan bahwa norma keluarga merupakan norma yang paling berperan dibandingkan norma kelompok sebaya. Penelitiberpendapat bahwa pada titikini, teori penilaian sosial (social judgement) bisa melengkapi teori disonansi kognitif Festinger. Teori penilaian sosial adalah teori yang dikembangkan oleh Muzafer Sheriff, dkk (1965), tentang bagaimana individu memberi penilaian berdasarkan pada acuan atau titik referensi dan keterlibatan ego. Acuan internal atau titik referensi selalu ada pada diri individu dan mempengaruhi cara orang merespon pesan ataupun informasi. Setiap individu akan memiliki referensi atau acuan. Terkait penelitian ini, acuan internal para informan adalah norma keluarga dan bukan norma kelompok. Dalam hal ini, norma keluarga yang merupakan norma yang menolak sikap permisif terhadap perilaku seks pranikah.

Lebih lanjut, dalam teori penilaian sosial dijelaskan bahwa pada masalah apapun, biasanya akan ada rentang pro dan kontra yang dapat ditolerir maupun ditolak. Rentang penerimaan dan penolakan seseorang dipengaruhi oleh sebuah variabel kunci: keterlibatan ego. Keterlibatan ego adalah tingkat relevansi individu terhadap suatu isu/masalah. Keterlibatan ego membuat perbedaan besar dalam hal bagaimana seseorang merespon informasi-informasi yang berhubungan dengan sebuah topik. Efek kontras akan terjadi saat individu menilai pesan berada jauh dari referensi atau acuan yang dimiliki. Sedangkan efek asimilasi terjadi saat individu menilai pesan berada dekat dengan referensi yang ada.

Terkait penelitian ini, yang terjadi adalah efek kontras. Hal ini dikarenakan sikap permisif terhadap perilaku seks pranikah berada jauh dari acuan/ referensi para informan yang mengacu pada norma keluarga.

Teori penilaian sosial juga membuat beberapa prediksi tentang perubahan sikap dalam komunikasi. Pertama, pesan-pesan yang berada dalam ruang penerimaan mempermudah terjadinya perubahan sikap. Kedua, jika suatu pesan dinilai berada dalam ruang penolakan, maka perubahan sikap akan berkurang atau bahkan tidak ada sama sekali. Ketiga, semakin dekat sebuah pesan yang berada di antara ruang penerimaan dan non komitmen dengan pendirian yang dimiliki, semakin besar kemungkinan terjadinya perubahan sikap. Dan akhirnya, semakin kuat keterlibatan ego dalam suatu masalah, semakin besar rentang penolakan, semakin kecil ruang tanpa komitmen, dan semakin kecil kemungkinan adanya perubahan sikap. Singkat kata, individu yang memiliki keterlibatan ego yang kuat sulit untuk dipengaruhi. Mereka cenderung menolak pesan ataupun informasi yang diterima, dibanding individu yang tidak memiliki keterlibatan ego yang kuat.

Pada penelitian ini, peneliti berpendapat terdapat keterlibatan ego yang kuat antara para informan dengan norma yang terbentuk dalam keluarga, sehingga sikap permisif terhadap perilaku seks pranikah berada dalam ruang penolakan. Yang berarti pula para informan menolak atau tidak menyetujui sikap permisif termaksud.

Denganmengintegrasikan teoridisonansikognitif dan teori penilaian sosial, peneliti berpendapat bahwa dinamika dan proses komunikasi untuk mencapai konsistensi kognitif dapat lebih dijelaskan dengan baik. Yaitu, disonansi muncul manakala individu mengalami inkonsistensi kognitif. Situasi yang tidak selaras ini akan memotivasi individu untuk mencapai harmoni. Dengan mengacu pada referensi ataupun acuan yang dimiliki dan memperhatikan keterlibatan ego, maka disonansi dapat diminimalisir. Lebih lanjut, norma akan berpengaruh tergantung sejauh mana norma tersebut menjadi acuan dari penilaian individu, dan seberapa kuat keterlibatan ego terbentuk pada norma yang ada.

\section{KESIMPULAN}

Secara umum, hasil penelitian memperlihatkan bahwa manakala ada pertentangan dua elemen kognitif maka akan muncul disonansi akibat inkonsistensi kognitif. Dua elemen kognitif yang bertentangan terkait penelitian adalah norma keluarga yang menegaskan bahwa perilaku seks pranikah adalah perilaku yang bertentangan dengan agama dan norma sosial/masyarakat, dan sikap permisif terhadap perilaku seks pranikah. Yaitu, sikap positif terhadap perilaku seks pranikah yang ditunjukkan dalam gaya berpacaran yang "serba boleh", mulai dari berciuman hingga akhirnya bersenggama, dimana sikap tersebut disepakati oleh kedua belah pihak atau "mau sama mau".

Lebih lanjut, hasil penelitian memperlihatkan bahwa jika individu mengalami disonansi maka akan ada upaya untuk mencapai konsistensi dalam 
kognitif. Misalnya, dengan melakukan perubahan pada salah satu elemen disonansi, seperti merubah keyakinan/kepercayaan atau merubah tindakan. Sebaliknya, jika individu berada dalam kondisi konsonan, maka individu tidak akan melakukan ataupun menambahkan elemen kognitif baru. Dalam hal ini termasuk upaya secara aktif untuk mencari informasi lain yang mendukung keyakinan yang dimiliki. Dan, agar tetap berada dalam konsistensi kognitif, proses komunikasi yang dilakukan adalah menurunkan arti penting dari elemen disonan, yaitu sikap permisif terhadap perilaku seks pranikah.

Terkait peran dari kelompok sebaya, penelitian ini memperlihatkan bahwa norma keluarga yang diperoleh melalui proses pendidikan keluarga lebih berperan dibandingkan norma kelompok sebaya, terkait sikap permisif terhadap perilaku seks pranikah. Norma keluarga telah menjadi acuan internal untuk menilai sebuah pesan yang diterima. Acuan ataupun referensi yang dimiliki oleh individu akan mampu menentukan perubahan sikap apa yang akan diterima serta perubahan apa yang akan ditolak. Setiap pesan atau informasi persuasif yang mendekati acuan atau referensi diri akan cenderung mendorong terjadinya perubahan sikap, dan sebaliknya.

\section{DAFTAR PUSTAKA}

Baron, R.A \& D. Bryne. (1994). Social Psychology: Understanding Human Interaction. Boston: Allyn \& Bacon.

Bem, D.J. (1967). Self-Perception: An Alternative Interpretation of Cognitive Dissonance Phenomena. Psychological Review, 74, 183-200.

Brown, Roger. (1965). Social Psychology, New York: Free Press.

Clayton, R.R. \& Bokemeier, J.L. (1980). Premarital Sex in the Seventies. Journal of Marriage and The Family, 42 : 34-50.

Damayanti, R. (2007). Peran Biopsikososial Terhadap Perilaku Berisiko Tertular HIV Pada Remaja SLTA Di DKI Jakarta, Jakarta, Disertasi FKM UI.

Faturochman. (1997). Sikap dan perilaku Seksual Remaja di Bali, Jurnal Psikologi 1, 12-17.
Festinger, Leon. (1957). A Theory of Cognitive Dissonance. Stanford, CA: Stanford University Press.

Griffin, EM, (2006). A First Look At Communication Theory, Sixth Edition, New York: McGraw Hill Companies, Inc.

Hall, Calvin.S, Lindsey, Gadner. (1978). Teori-Teori Holistik (Organismik-Fenomenologi), Yogyakarta: Penerbit Kanisius.

Littlejohn, Stephen W. (2002). Theories of Human Communication, Seventh Edition, Belmont, California: Wardsworth/Thomas Learning.

Littlejohn, Stephen W, Foss, Karen. (2005). Theories of Human Communication, $8^{\text {th }}$ Edition, Belmont, CA: Wadsworth.

O'Keefe, D. J. (2002). Persuasion: Theory and research (2nd ed.), Thousand Oaks, CA: Sage.

Perlof, Richard M. (2010). The Dynamics of Persuasion: Communication and Attitudes in The 21st, $4^{\text {th }}$ edition, New York: Lawrence Erlbaum Associates.

Samovar, L.A., Porter, Richard., McDaniel, Edwin. (2010). Communication Between Cultures, Singapore: Cengeage Learning Asia Pte Ltd

Sarlito Wirawan, Sarwono. (1999). Psikologi Sosial: Individu dan Teori-Teori Psikologi Sosial, Jakarta: Balai Pustaka.

(2001). Psikologi Sosial : Psikologi Sosial: Psikologi Kelompok dan Psikologi Terapan, Jakarta: Balai Pustaka. . (2007). Psikologi Remaja (6 $6^{\text {th }}$ ed.), Jakarta: PT. Raja Grafindo Persada.

Sears, David O, Freedman, Jonathan L, Peplau, Anne L. (1985). Social Psychology, Fifth Edition, Prentice Hall, Inc.

Smith, Jonathan A. dan Mike Osbom. (2009). Psikologi Kualitatif: Petunjuk Praktis untuk Metode Penelitian. Yogyakarta: Pustaka Pelajar.

Tankard, James W Jr. dan Werner J Severin. (2008). Teori Komunikasi, Jakarta: Prenada Media Group.

West. Richard, Turner. Lynn H. (2007). Introducing Communication Theory: Analysis and Application, 3rd edition, New York: McGraw Hill.

Zajonc, R.B. "Leon Festinger (1919-1989)", American Psychologist, vol.45, 1990, 661. 